\title{
Studi Karakterisasi Listrik Sel Surya Polimer Hibrid Berbasis P3HT-ZnO pada Substrat Fleksibel
}

\author{
Rifan Satiadi* \\ Program Studi Fisika, FPMIPA, Universitas Pendidikan Indonesia \\ Jl. Dr Setiabudi no. 229, Bandung 40154 \\ Erlyta Septa Rosa dan Shobih \\ Pusat Penelitian Elektronika dan Telekomunikasi-Lembaga Ilmu Penelitian Indonesia (PPET-LIPI) \\ Kampus LIPI Jl. Sangkuriang Bandung 40135
}

\begin{abstract}
Kebutuhan untuk memperoleh sumber energi yang bersih dan terbarukan telah mendorong para peneliti untuk mengembangkan sel surya sebagai salah satu energi alternatif. Sel surya dengan bahan organik telah dikembangkan karena mempunyai potensi untuk diproduksi dengan biaya yang lebih murah, proses yang lebih mudah, dan dapat dikembangkan dengan substrat yang fleksibel/plastik. Salah satu pengembangan sel surya organik adalah sel surya polimer berbahan dasar polimer. Tulisan ini melaporkan hasil studi karakteristik listrik sel surya polimer hibrid menggunakan lapisan aktif campuran polimer P3HT dan semikonduktor ZnO diatas substrat fleksibel (PET). Sel surya polimer hibrid tersebut mempunyai struktur PET/ITO/PEDOT: PSS/P3HT-ZnO/Al dengan luas daerah aktifnya sebesar $2,6 \mathrm{~cm}^{2}$. Karakterisasi sifat listrik dilakukan dengan menyinari sel menggunakan sumber cahaya lampu xenon dengan intensitas penyinaran cahaya 270,600 , dan $1000 \mathrm{~W} / \mathrm{m}^{2}$. Karakteristik listrik pada intensitas penyinaran $270 \mathrm{~W} / \mathrm{m}^{2}$ memiliki performansi yang paling baik dengan efisiensi konversi $0,024 \%$, fill factor 0,63 , tegangan open circuit sebesar $0,477 \mathrm{~V}$, arus short circuit sebesar $5,6 \times 10^{-5}$ A, dan daya maksimum yang dihasilkan sebesar $1,68 \times 10^{-5}$ Watt.
\end{abstract}

\begin{abstract}
Need to obtain a source of clean and renewable energy has prompted researchers to develop solar cells as one of the alternative energy. Solar cells with organic materials have been developed as it has the potential to be produced at lower cost, easier to process, and can be developed with a flexible substrate/plastic. One is the development of organic solar cells polymer solar cells made from polymers. This paper reports the results of the study of electrical characteristics of hybrid polymer solar cells using P3HT polymer blend active layer and the semiconductor $\mathrm{ZnO}$ on flexible substrates (PET). The hybrid polymer solar cells have a structure of PET/ITO/PEDOT:PSS/P3HT-ZnO/Al with an area of $2.6 \mathrm{~cm}^{2}$ active area. Characterization of the electrical properties is done by irradiating the cells using a light source with a xenon lamp light irradiation intensity 270 , 600 , and $1000 \mathrm{~W} / \mathrm{m}^{2}$. Electrical characteristics at $270 \mathrm{~W} / \mathrm{m}^{2}$ irradiation intensity has the best performance with a conversion efficiency of $0.024 \%, 0.63$ fill factor, open-circuit voltage of $0.477 \mathrm{~V}$, short circuit current of $5.6 \times$ $10^{-5} \mathrm{~A}$, and the maximum power result of $1.68 \times 10^{-5}$ Watt.
\end{abstract}

KATA KUNCI: hybrid polymer solar cells, electrical characteristics, P3HT: ZnO

\section{PENDAHULUAN}

Kebutuhan untuk memperoleh sumber energi yang bersih dan terbarukan telah mendorong para peneliti untuk mengembangkan sel surya sebagai salah satu energi alternatif. Sampai saat ini sel surya yang ada di pasaran industri menggunakan bahan semikonduktor anorganik sebagai material utamanya, yaitu silikon. Silikon mendominasi bahan sel surya karena karena teknologi fabrikasinya memang sudah mapan. Di satu sisi tingkat efisiensi sel surya anorganik mencapai angka yang tinggi, tetapi di sisi lain proses pembuatan divais tersebut tidak sederhana, membutuhkan biaya pembuatan yang tinggi dan

\footnotetext{
*E-MAIL: rifansatiadi@gmail.com
}

bentuknya cenderung kaku [1]. Disamping itu dalam pembuatan divais fotovoltaik anorganik terdapat limbah yang dapat merusak lingkungan disekitarnya seperti racun silikon dan polusi udara dari industri pembuatan divais tersebut [2]. Hal ini membuat para peneliti berusaha mencari divais sejenis yang dapat dibuat dengan proses yang sederhana, ramah lingkungan serta ongkos pembuatan yang murah. Salah satu bahan yang terus dikembangkan oleh para peneliti untuk mengatasi masalah tersebut adalah bahan organik. Beberapa material yang dapat digunakan sebagai lapisan aktif dalam sel surya organik antara lain adalah molekul kecil, polimer terkonjugasi, kombinasi dari molekul kecil dengan polimer terkonjugasi, atau kombinasi material organik dan anorganik [3].

Sel surya dengan bahan polimer terkonjugasi telah dikembangkan karena mempunyai potensi untuk diproduksi dengan biaya yang lebih murah, proses yang lebih mudah, dan da- 


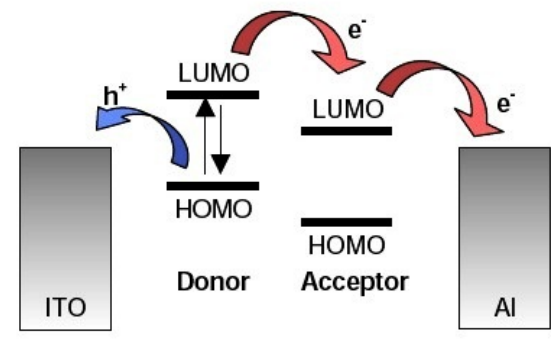

Gambar 1: Skema level energi sel surya polimer hibrid [11].

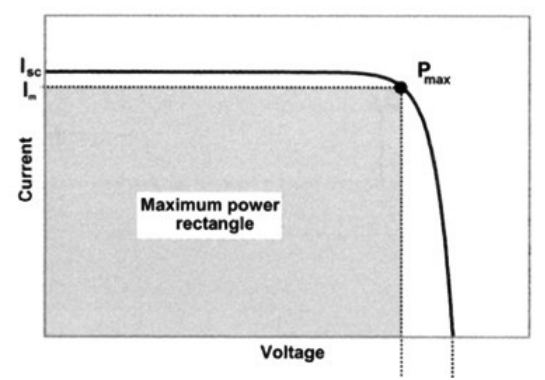

Gambar 2: Kurva I-V sel surya. pat dikembangkan dengan substrat yang fleksibel/plastik [4]. Meskipun demikian efisiensi yang dihasilkan masih lebih rendah dibandingkan dengan sel surya silikon, sehingga masih banyak peluang yang dapat dilakukan untuk mengembangkan sel surya berbasis polimer ini secara intensif.

Polimer terkonjugasi dapat juga dikombinasikan dengan semikonduktor anorganik tipe-n seperti $\mathrm{ZnO}$ dan $\mathrm{TiO}_{2}$ [5]. Pada sel surya hibrid polimer/semikonduktor anorganik, kelebihan dari kedua material ini digabungkan. Material polimer terkonjugasi merupakan semikonduktor yang dapat dilarutkan dalam proses fabrikasi sedangkan material semikonduktor anorganik memiliki mobilitas elektron yang tinggi [3].

Ji [6] melaporkan hasil penelitian sel surya hibrid campuran polimer P3HT poly(3-hexythiophene) dengan nanopartikel $\mathrm{ZnO}$ (Zinc Oxide) dengan efisiensi 0,020\%. Dalam tulisan Wang [7], arus mengalami peningkatan dari 6,35 $\mathrm{mA} / \mathrm{cm}^{2}$ menjadi $9,55 \mathrm{~mA} / \mathrm{cm}^{2}$ pada saat penambahan Perylene derivative (PDI) ke campuran P3HT-ZnO. Li [8] melaporkan efisiensi sel surya polimer hibrid P3HT:DOPO-ZnO sebesar 0,077\% . Baik Ji [6] dan Li [8] penelitian sel surya polimer hibrid dibuat di atas substrat kaca.

Sekarang ini penggunaan substrat yang bersifat fleksibel sebagai pengganti kaca telah menjadi penelitian yang sangat menarik karena memiliki beberapa kelebihan. Beberapa kelebihannya adalah proses serta penanganan yang lebih mudah, aplikasi yang lebih luas, suhu proses fabrikasi rendah $\left(<150^{\circ} \mathrm{C}\right)$, serta mudah diproduksi secara massal atau dalam skala industri menggunakan sistem roll to roll [4].

Tulisan ini melaporkan hasil studi karakteristik listrik sel surya polimer hibrid menggunakan lapisan aktif campuran polimer P3HT dan semikonduktor $\mathrm{ZnO}$ di atas substrat fleksibel (PET). Karakterisasi sifat listrik dilakukan dengan menyinari sel menggunakan sumber cahaya lampu xenon dengan intensitas penyinaran cahaya 270, 6000, dan $1000 \mathrm{~W} / \mathrm{m}^{2}$.

\section{DASAR TEORI}

\section{Hybrid Bulk Heterojunction}

Bulk heterojunction (BHJ) merupakan konsep yang umum diterapkan pada pembuatan sel surya polimer. Pengembangan dari konsep BHJ adalah hybrid bulk heterojunction, yaitu mencampurkan material semikonduktor organik dan material semikonduktor anorganik sebagai lapisan aktif sel surya [3].

\section{Prinsip Dasar Sel Surya Polimer Hibrid}

Prinsip dasar dalam sel surya bahan polimer hibrid hampir sama dengan bahan sel surya polimer/fullerene. Bagian ter-atas dari keadaan yang ditempati oleh elektron pada pita valensi disebut Highest Occupied Molecular Orbital (HOMO), sedangkan bagian terbawah dari keadaan yang tidak ditempati elektron pada pita disebut dengan Lowest Unoccupied Molecular Orbital (LUMO) [9].

Pada sel surya polimer hibrid, yang berperan sebagai donor adalah polimer P3HT dan material anorganik ZnO sebagai akseptor [5]. Level energi pada P3HT adalah HOMO 5,2 eV dan LUMO 3,53 eV [10], sedangkan level energi pada $\mathrm{ZnO}$ adalah pita valensi 7,6 eV dan pita konduksi 4,4 eV relatif terhadap level vakum [3]. Skema level energi dapat dilihat Gambar 1.

Menurut Saunders pembentukan arus penyinaran pada sel surya hibrid ini terdapat beberapa langkah yaitu [12]:

1. Penyerapan foton oleh material polimer yang terdapat pada lapisan aktif. Foton ini kemudian akan membangkitkan eksiton (pasangan elektron-hole)

2. Difusi eksiton

3. Pemisahan eksiton menjadi muatan bebas terjadi pada interface donor-akseptor

4. Transport muatan

5. Pengumpulan muatan terjadi pada masing-masing elektroda, pada anoda akan terkumpul hole (pembawa muatan positif) dan pada katoda akan terkumpul elektron (pembawa muatan negatif).

\section{Karakterisasi}

Salah satu dari pengukuran dasar untuk menentukan karakteristik sel surya baik anorganik atau organik adalah pengukuran arus-tegangan (I-V). Pengukuran arus-tegangan (IV) di lakukan dengan menyinari divais sel surya dibawah penyinaran standar spektrum matahari AM1.5 $\left(1000 \mathrm{~W} / \mathrm{m}^{2}\right)$. 


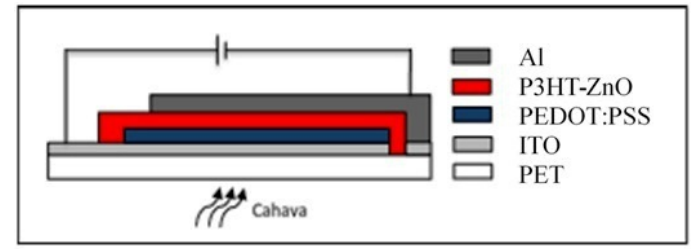

Gambar 3: Skema sel surya hybrid bulk heterojunction.

Dari hasil pengukuran I-V tersebut dapat diperoleh kurva I-V seperti yang ditampilkan pada Gambar 2 .

Beberapa parameter yang penting yang digunakan untuk mengkarakterisasi sel surya dapat diperoleh dari kurva I-V adalah arus short-circuit $\left(\mathrm{I}_{s c}\right)$, tegangan open-circuit $\left(\mathrm{V}_{o c}\right)$, daya maksimum $\left(\mathrm{P}_{m}\right)$, fill factor $(\mathrm{FF})$, dan efisiensi konversi daya $(\eta)$.

Efisiensi konversi $(\eta)$ didefinisikan sebagai perbandingan antara daya listrik maksimum dan daya matahari yang datang pada sel surya:

$$
\begin{aligned}
\eta & =\frac{P_{\text {out }}}{P_{\text {in }}} \\
& =\frac{F F \times V_{o c} \times I_{s c}}{P_{\text {in }}} \times 100 \%
\end{aligned}
$$

Arus short circuit $\left(\mathrm{I}_{s c}\right)$ didefinisikan arus ketika rangkaian terhubung pendek $(\mathrm{V}=0)$ merupakan parameter fotovoltaik yang menggambarkan arus foto maksimum yang dapat dihasilkan oleh sel surya [13]. Tegangan open-circuit $\left(\mathrm{v}_{o c}\right)$ menggambarkan mekanisme tidak adanya arus yang mengalir di dalam sel $(\mathrm{I}=0)$. Pada keadaan ini pita energi dari material berada dalam keadaan sejajar sehingga tidak ada medan listrik di dalam material, akibatnya tidak ada muatan yang dapat di konversi menjadi arus [13]. Fill factor sel surya merupakan perbandingan antara daya keluaran maksimum terhadap daya teoritisnya atau dapat dinyatakan sebagai berikut :

$$
F F=\frac{v_{m} J_{m}}{V_{o c} J_{s c}}
$$

Kualitas dari sel surya biasanya dinyatakan dengan nilai FF yang menunjukkan besarnya kemampuan sel surya menyerap cahaya yang diterimanya. Dalam kaitan dengan kualitas dioda, batas nilai FF adalah kurang dari nilai ideal yaitu 1. Karakteristik dioda akan menyimpang dari nilai ideal, terutama diakibatkan oleh rekombinasi yang terjadi pada junction. Untuk sel surya organik dan sel surya hibrid junction yang dimaksud adalah interface donor-akseptor, yang mana terdistribusi di seluruh lapisan aktif [13].

\section{METODOLOGI}

\section{Fabrikasi}

Struktur sel surya dibuat hybrid bulk heterojunction dengan konfigurasi pada Gambar 3. Substrat PET yang telah dilapisi

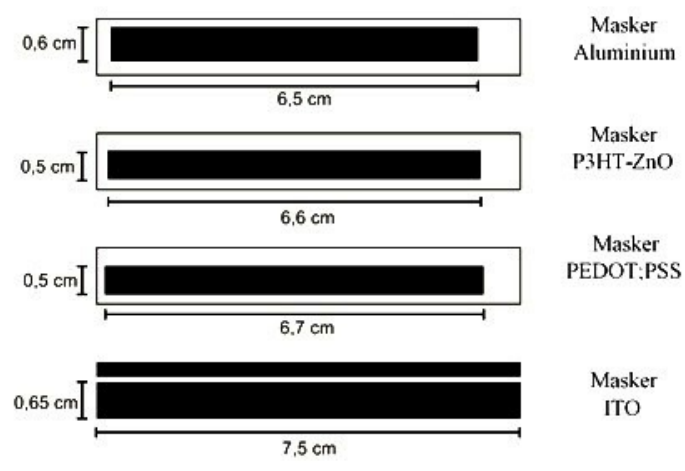

Gambar 4: Pola masker.

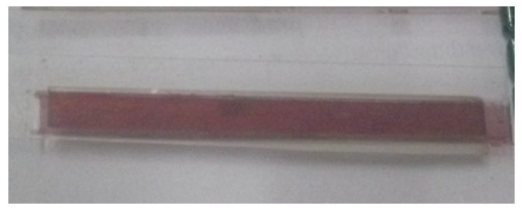

Gambar 5: Sel surya polimer hibrid substrat fleksibel.

oleh ITO (Aldrich) dengan dimensi $1 \mathrm{~cm} \times 7,5 \mathrm{~cm}$ ketebalan ITO $100 \mathrm{~nm}$ dan resitansi permukaan $60 \Omega / \mathrm{sq}$. ITO ditutupi oleh fotoresist, kemudian disinari dengan sinar UV selama 2 menit dengan masker ITO (Gambar 4) diletakkan di atasnya. Kemudian ITO di etching dengan menggunakan $\mathrm{HCl} 50 \%$ selama 3 menit. Setelah etching, dilanjutkan proses stripping menggunakan aseton untuk menghilangkan fotoresist. Substrat dicuci menggunakan DI water, sabun cair dan IPA (isopropyl alcohol) di dalam ultrasonic cleaner.

PEDOT:PSS (Agfa) dilapisi dengan teknik screen printing sesuai masker PEDOT:PSS (Gambar 4). Pengeringan suhu kamar 10 menit, lalu dipanaskan selama 60 menit pada suhu $100^{\circ} \mathrm{C}$ keadaan vakum. P3HT (Aldrich) dilarutkan kedalam chlorobenzene dan $\mathrm{ZnO}$ (Aldrich) dilarutkan kedalam chlorobenzene ditambah methanol (rasio massa P3HT-ZnO = 2,5:1). Setelah \pm 24 jam campurkan kedua larutan dan kocok hingga merata. Pelapisan polimer hibrid sesuai masker P3HT-ZnO (Gambar 4) dilakukan dengan teknik spin coating $1500 \mathrm{rpm}$ selama 0,5 menit, drying suhu kamar \pm 24 jam dalam keadaan vakum. Evaporasi aluminium dengan masker aluminium (Gambar 4) pada tekanan 5-6 $\times 10^{-5}$ mBar selama 5 menit dengan ketebalan $50 \mathrm{~nm}$, membentuk daerah aktif sebesar $2,6 \mathrm{~cm}^{2}$. PET ukuran $6,5 \mathrm{~cm} \times 0,7 \mathrm{~cm}$ dibuat untuk menutupi bagian belakang sel surya. Sealant (Dyesol) diletakkan antara sel surya dengan PET dan di oven pada temperatur $100^{\circ} \mathrm{C}$ selama 10 menit dalam keadaan vakum. Prototipe sel surya polimer hibrid substrat fleksibel dapat dilihat pada Gambar 5.

\section{Pengukuran arus tegangan}

Pengukuran arus-tegangan (I-V) di lakukan dengan menyinari divais sel surya di bawah penyinaran standar spektrum 
TABEL I: Karakteristik Listrik Sel Surya Polimer Hibrid berbasis P3HT-ZnO

\begin{tabular}{lccc}
\hline \hline Karakteristik & \multicolumn{3}{c}{ Intensitas Penyinaran $\left(\mathrm{W} / \mathrm{m}^{2}\right)$} \\
Listrik & 270 & 600 & 1000 \\
\hline Tegangan Open circuit $\mathrm{V}_{o c}(\mathrm{~V})$ & 0,477 & 0,538 & 0,652 \\
Arus Short circuit $\mathrm{I}_{s c}(\mathrm{~A})$ & $5,6 \times 10^{-5}$ & $5,83 \times 10^{-5}$ & $6,04 \times 10^{-5}$ \\
Tegangan Maksimum Vm (V) & 0,348 & 0,342 & 0,505 \\
Arus Maksimum $\mathrm{I}_{m}(\mathrm{~A})$ & $4,83 \times 10^{-5}$ & $4,34 \times 10^{-5}$ & $3,59 \times 10^{-5}$ \\
Daya Maksimum $\mathrm{P}_{m}$ (Watt) & $1,68 \times 10^{-5}$ & $1,49 \times 10^{-5}$ & $1,81 \times 10^{-5}$ \\
Fill factor FF & 0,63 & 0,47 & 0,46 \\
$\mathrm{R}$ series (Ohm) & 4204 & 1675 & 1223 \\
Efisiensi koversi $\eta(\%)$ & 0,024 & 0,009 & 0,007 \\
\hline
\end{tabular}

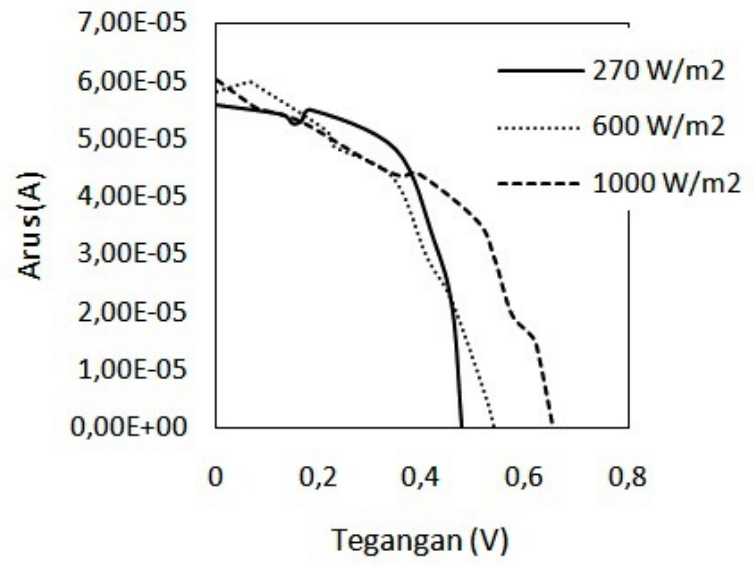

Gambar 6: Kurva I-V sel surya polimer hibrid P3HT-ZnO pada berbagai intensitas cahaya penyinaran.

matahari AM1.5 $\left(1000 \mathrm{~W} / \mathrm{m}^{2}\right)$ menggunakan solar simulator dengan lampu xenon. Intensitas penyinaran sebesar 270 $\mathrm{W} / \mathrm{m}^{2}, 600 \mathrm{~W} / \mathrm{m}^{2}$, dan $1000 \mathrm{~W} / \mathrm{m}^{2}$ dengan temperatur $27^{\circ} \mathrm{C}$. Alat pengukuran menggunakan I-V Measurement dari National Instrument.

\section{HASIL DAN DISKUSI}

Gambar 6 menunjukan kurva I-V saat penyinaran dengan intensitas penyinaran 270,600, dan $1000 \mathrm{~W} / \mathrm{m}^{2}$. Karakteristik listrik sel surya polimer hibrid berbasis P3HT-ZnO ditunjukan dalam Tabel I. Nilai $\mathrm{V}_{o c}$ dan $\mathrm{I}_{s c}$ mengalami peningkatan ketika intensitas penyinaran meningkat. Intensitas penyinaran menyebabkan elektron-elektorn yang terlepas semakin banyak sehingga arus listrik meningkat. Nilai R series mengalami penurunan ketika intensitas penyinaran meningkat, hal ini juga berpengaruh pada peningkatan $\mathrm{I}_{s c}$ ketika intensitas penyinaran meningkat. Hasil ini sebanding dengan hasil yang diperoleh oleh Beek yang menggunakan polimer hibrid MDMO-PPV:ZnO [3], disebutkan bahwa nilai $\mathrm{V}_{o c}$ dan $\mathrm{I}_{s c}$ meningkat dengan meningkatnya intensitas penyinaran.

Menurut Scharber dkk pada sel surya polimer/fullerene, nilai maksimum $\mathrm{V}_{o c}$ adalah selisih dari level HOMO pada material donor (polimer) dengan level LUMO material akseptor (fullerene) [14], memenuhi persamaan:

$$
\begin{aligned}
V_{o c} & =\left(\frac{1}{e}\right)\left(\left|E^{\text {donor }} H O M O\right|-\left|E^{\text {akseptor }} L U M O\right|\right) \\
& -0,3 V
\end{aligned}
$$

Pada sel surya polimer hibrid, semikonduktor anorganik berperan sebagai akseptor. Sehingga Pers.(3) dapat digunakan untuk sel surya polimer hibrid, dengan perbedaan pada level energi konduksi akseptor. Sehingga nilai maksimum Voc dari sel surya polimer hibrid P3HT:ZnO adalah sekitar 0,5 V. Pada intensitas $1000 \mathrm{~W} / \mathrm{m}^{2}, \mathrm{~V}_{o c}$ paling tinggi bernilai $0,652 \mathrm{~V}$. Hasil ini masih tinggi dibandingkan dengan hasil yang diperoleh Ji [6] sebesar 0,32 V dan Li [8] sebesar 0,341.

Akibat arus keluaran yang dihasilkan kecil sekitar 6,04 $\times$ $10^{-5} \mathrm{~A}$, maka daya maksimum juga kecil yaitu dalam orde mikrowatt jika dibandingkan dengan sel surya ideal dengan orde miliwatt. Rapat arus yang dihasilkan sebesar 0,023 $\mathrm{mA} / \mathrm{cm}^{2}$. Hasil ini lebih rendah dari hasil yang dilaporkan oleh Ji [6] sebesar $0,16 \mathrm{~mA} / \mathrm{cm}^{2}$ dan Li [8] sebesar 1,05 $\mathrm{mA} / \mathrm{cm}^{2}$. Pada substrat kaca umumnya arus yang dihasilkan akan lebih besar dibandingkan dengan substrat PET, karena sheet resistivity ITO pada substrat kaca lebih rendah $(12 \Omega / \mathrm{sq})$ dibandingkan dengan PET (60 $\Omega /$ sq).

Pada intensitas penyinaran $270 \mathrm{~W} / \mathrm{m}^{2}$ ke $600 \mathrm{~W} / \mathrm{m}^{2}$, daya maksimum mengalami penurunan. Namun pada intensitas penyinaran $1000 \mathrm{~W} / \mathrm{m}^{2}$, daya maksimum mengalami peningkatan. Hal ini dikarenakan $\mathrm{P}_{m}$ merupakan perkalian antara $\mathrm{V}_{m}$ dan $\mathrm{I}_{m}$, dimana $\mathrm{V}_{m}$ mengalami penurunan pada intensi$\operatorname{tas} 270 \mathrm{~W} / \mathrm{m}^{2} \mathrm{ke} 600 \mathrm{~W} / \mathrm{m}^{2}$ dan mengalami pening-katan pada intensitas penyinaran $1000 \mathrm{~W} / \mathrm{m}^{2}$. Sedangkan $\mathrm{I}_{m}$ mengalami penurunan ketika intensitas penyinaran meningkat.

Pada intensitas penyinaran $1000 \mathrm{~W} / \mathrm{m}^{2}$, nilai FF sel surya ini adalah 0,46. Nilai FF ini lebih tinggi dibandingkan dengan hasil yang diperoleh peneliti lain yang menggunakan substrat kaca seperti Ji [6] sebesar 0,39 dan Li [8] sebesar 0,21. Untuk meningkatkan nilai FF salah satunya adalah dengan mengurangi nilai resistansi sel surya. Efisiensi konversi sel surya pada intensitas penyinaran $1000 \mathrm{~W} / \mathrm{m}^{2}$ adalah sebesar $0,007 \%$ masih rendah dibandingkan dengan hasil-hasil yang diperoleh peneliti dahulu yang menggunakan substrat kaca seperti Ji [6] sebesar 0,020\% dan Li [8] sebesar 0,077\%. Rendahnya efisiensi konversi diakibatkan oleh rendahnya arus yang dihasilkan akibat dari tingginya sheet resistivity kontak ITO yang ada pada substrat fleksibel. 
Berdasarkan kurva I-V pada Gambar 6, peningkatan intensitas penyinaran mengakibatkan semakin rendahnya gradien pada kurva IV. Hal ini menggambarkan peningkatan intensitas penyinaran menyebabkan FF mengalami penurunan. Hasil ini sebanding dengan hasil yang diperoleh oleh Beek [3] yang menggunakan substrat kaca, dimana disebutkan bahwa FF mengalami penurunan terhadap peningkatan intensitas penyinaran. Penurunan FF ini mengakibatkan nilai efisiensi konversi mengalami penurunan ketika intensitas penyinaran meningkat. Meningkatnya intensitas penyinaran akan mengakibatkan terjadinya degradasi pada sel surya polimer hibrid, sehingga FF dan efisiensi konversi mengalami penurunan.

\section{Ucapan Terima Kasih}

Penelitian ini terlaksana atas pendanaan dari DIPA TEMATIK PPET-LIPI 2013.

\section{SIMPULAN}

Pada sel surya polimer hibrid berbasis P3HT-ZnO, semakin besar intensitas penyinaran cahaya, tegangan open circuit dan arus short circuit semakin besar. Hambatan series dan arus maksimum mengalami penurunan ketika intensitas penyinaran bertambah. Daya maksimum dan tegangan maksimum mengalami peningkatan pada intensitas $270 \mathrm{~W} / \mathrm{m}^{2}$ ke 600 $\mathrm{W} / \mathrm{m}^{2}$ dan mengalami penurunan pada intensitas penyinaran $1000 \mathrm{~W} / \mathrm{m}^{2}$. Sedangkan efisiensi dan fill factor mengalami penurunan ketika intensitas penyinaran bertambah. Karakteristik listrik pada intensitas penyinaran $270 \mathrm{~W} / \mathrm{m}^{2}$ memiliki performansi yang paling baik dengan efisiensi konversi $0,024 \%$, fill factor 0,63 , tegangan open circuit sebesar 0,477 $\mathrm{V}$, arus short circuit sebesar 5,6 $\times 10^{-5} \mathrm{~A}$, dan daya maksimum yang dihasilkan sebesar $1,68 \times 10^{-5}$ Watt.
[1] T.D. Nielsen, et al., Solar Energy Materials and Solar Cells, 94, 1553-1571 (2010).

[2] I. Nath, Stanford Journal of International Relations, XI (2), 6-16 (2010).

[3] W.J.E. Beek, et al., J. Phys. Chem B 109, 9505-9516 (2005).

[4] F. Krebs, Solar Energy Materials and Solar Cells 93, 465-475 (2009).

[5] J. Chandrasekaran, et al., Renewable and Sustaninable Energy Reviews 15, 1228-1238 (2011).

[6] L.W. Ji, et al., J. Mater. Sci., 45, 3266-3269 (2007).

[7] M. Wang, and X. Wang, Solar Energy Materials and Solar Cells 92, 776-771 (2008).
[8] F. Li, et al., Solar Energy Materials and Solar Cells 97, 64-70 (2010).

[9] Rockett, The materials science of semiconductors (Springer, University of Illinois, 2007).

[10] M. Al-Ibrahim, et al., Organic Electronics 6, 65-77 (2005).

[11] H. Spanggaard, and F.C. Krebs, Solar Energy Materials and Solar Cells 83, 125-146 (2004).

[12] B. Saunders, J. Colloid and Interface Science 369, 1-15 (2012).

[13] M. Wright, and A. Uddin, Solar Energy Materials and Solar Cells 107, 87-111 (2012).

[14] M. Scharber, et al., J. Advanced Materials 18, 789-794 (2006). 